Henry K. Gyasi MB CHB FFARCSI, Mohamed Naguib MB, BCH MSC, Yaw Adu-Gyamfi MB CH B FFARCS FWACS

\section{Atracurium for short surgical procedures: a comparison with succinylcholine}

Atracurium besylate is a new non-depolarising neuromuscular blocking agent. Initial clinical studies have shown that it has an intermediate duration of action, is easily reversed with anticholinesterase drugs and has minimal side effects. ${ }^{1-4}$ These properties fulfill some of the criteria suggested for an ideal muscle relaxant for short surgical procedures lasting 30 minutes or less. ${ }^{5}$ Muscle relaxation for such procedures is usually produced with succinylcholine, given as a continuous infusion or as intermittent injection. However, succinylcholine has many side effects, including cardiovascular changes, muscle fasciculations, hyperkalaemia, increased intracranial, intragastric and intraocular pressures, postoperative muscle pains, phase II block following large doses and malignant hyperpyrexia. ${ }^{6}$

Previous studies have shown that vecuronium (ORG NC 45) $100 \mu \mathrm{g} \cdot \mathrm{kg}^{-1}$ can be used for short intra-abdominal operations but the onset of action is prolonged in comparison with succinylcholine. ${ }^{5}$ The non-depolarising muscle relaxants, d-tubocurarine, pancuronium, gallamine, alcuronium and fazadinium all have a slow onset, long duration of action and undesirable side effects ${ }^{7}$ which would make them unsuitable for short surgical procedures.

Our study was designed to compare atracurium $400 \mu \mathrm{g} \cdot \mathrm{kg}^{-1}$ with intermittent injections of succinylcholine in patients undergoing various gynaecological procedures lasting less than 30 minutes. Using a simple method of monitoring neuromuscular function, comparisons were made of the onset and duration of action, intubating conditions and recovery from neuromuscular activity for both drugs.

\section{Methods}

Forty women aged between 16-60 years undergoing minor gynaecological procedures were studied. All were of A.S.A. physical status I, were free from 
neuromuscular, renal or hepatic disease and were not taking any drugs known to interfere with neuromuscular function. Informed consent was obtained from each patient. All patients were pre-medicated with diazepam $150 \mu \mathrm{g} \cdot \mathrm{kg}^{-1}$ orally one and a half hours preoperatively and atropine $0.6 \mathrm{mg}$ intramuscularly, one hour before surgery.

An intravenous infusion of Ringer's Lactate in five per cent dextrose was established prior to induction. The E.K.G. was monitored continuously by an M.1 Medishield monitor and arterial blood pressure was monitored every five minutes by an electronic oscillotonometer (Dinamap).

Neuromuscular activity was assessed by observation of thumb adduction, using a Bard peripheral nerve stimulator applying supramaximal stimuli to the ulnar nerve at the wrist via surface electrodes. Observation of thumb adduction was made easier by fixing the medial four fingers with adhesive tape to an armboard and the arm abducted to approximately $90^{\circ}$. Train of four (TOF) stimuli of $2 \mathrm{msec}$ duration and 2 hertz frequency, produced every 12 seconds were used throughout the study.

Anaesthesia was induced with fentanyl, 1 $\mu \mathrm{g} \cdot \mathrm{kg}^{-1}$, followed by thiopentone $3-5 \mathrm{mg} \cdot \mathrm{kg}^{-1}$ intravenously. For muscle relaxation, the patients were divided into two groups by random allocation. Group $A$, the study group, received atracurium $400 \mu \mathrm{g} \cdot \mathrm{kg}^{-1}$ and Group B, the control group received succinylcholine $1 \mathrm{mg} \cdot \mathrm{kg}^{-1}$ following induction. In Group B, succinylcholine $0.25 \mathrm{mg} \cdot \mathrm{kg}^{-1}$ was given whenever response to TOF stimulation returned during surgery.

Tracheal intubation was performed when response to TOF stimulation disappeared. Intubation conditions were compared using the method of Fahey $e t$ al. ${ }^{8}$ (Table I). Intubating conditions were assessed by the same anaesthetist who at the time was unaware of the identity of the muscle relaxant used. Anaesthesia was maintained with 66 per cent nitrous oxide in oxygen and halothane 0.5-1 per cent inspired. Ventilation was controlled manually before intubation and subsequently with a Manley "servovent" to maintained normocapnia. End tidal $\mathrm{CO}_{2}$ was monitored by a Datex Normocap infrared carbon dioxide analyser.

At the end of surgery, halothane and nitrous oxide were discontinued and in the study group, neuromuscular block was reversed with neostigmine $0.036 \mathrm{mg} \cdot \mathrm{kg}^{-1}$ and atropine $0.018 \mathrm{mg} \cdot \mathrm{kg}^{-1}$.
TABLE I Scoring of intubation conditions (Fahey et al.)

\begin{tabular}{cc}
\hline Score & Intubating conditions \\
\hline 0 & $\begin{array}{c}\text { Cords abducted, good visualisation, no patient } \\
\text { movement. }\end{array}$ \\
1 & $\begin{array}{c}\text { Cords abducted, good visualisation, diaphragmatic } \\
\text { movement with intubation. }\end{array}$ \\
2 & $\begin{array}{c}\text { Cords slightly abducted, poor visualisation, } \\
\text { coughing with intubation. }\end{array}$ \\
3 & Cords moderalely abducted, poor visualisation, gross \\
body movements with intubation.
\end{tabular}

Half of this dose of neostigmine and atropine was repeated if all four responses of TOF stimulation had not returned or if there was any visible fade of response to TOF stimulation, ten minutes following reversal.

After the return of all responses of TOF stimulation, the patients were extubated when spontaneous respiration had returned and tidal volume was assessed to be clinically adequate. Head lift in response to command was assessed every five minutes after extubation until head lift was sustained for five seconds or more.

Values are presented as mean and standard deviation. Statistical analysis was performed using Student's $t$ test to compare the onset of action of both drugs. Intubating scores and time to respond to sustained head lift on command were compared using Chi square test with Yates correction factor. Differences were considered significant when $\mathrm{p}<$ 0.05 .

\section{Results}

There was no statistical difference between the two groups with respect to age and body weight (Table II).

The duration of anaesthesia in all cases was less than 30 minutes and the mean time of surgery was $17.65 \pm 5.3$ minutes for the atracurium group and $15.2 \pm 4.6$ minutes for the succinylcholine group (Table II) (P = N.S.).

Complete twitch suppression to TOF stimulation was produced in $76.8 \pm 39.3$ seconds by succinylcholine and $198.3 \pm 84.1$ seconds by atracurium (Table III) $(p<0.01)$.

Intubating conditions were satisfacotry in all patients (intubating scores of two or less). In the atracurium group, intubating scores were graded as zero in ten patients, one in five patients and two in 
TABLE II Age, body weight, dose of muscle relaxants and duration of surgery

\begin{tabular}{lcccc}
\hline & Age $(y \mathrm{rs})$ & B.W. $(\mathrm{kg})$ & $\begin{array}{l}\text { Total dose of } \\
\text { relaxant }(\mathrm{mg})\end{array}$ & $\begin{array}{l}\text { Duration of } \\
\text { surgery (min) }\end{array}$ \\
\hline $\begin{array}{l}\text { Group } \mathrm{A}, \mathrm{n}=20 \\
\text { (Acracurium) }\end{array}$ & $36.0 \pm 11.2$ & $66.7 \pm 9.8$ & $26.7 \pm 3.9$ & $17.6 \pm 5.3$ \\
$\begin{array}{l}\text { Group B, } \mathrm{n}=20 \\
\text { (Succinylcholine) }\end{array}$ & $32.6 \pm 8.8$ & $66.1 \pm 14.4$ & $103.3 \pm 27.1$ & $15.2 \pm 4.6$ \\
\hline
\end{tabular}

(Mean \pm S.D.). There were no statistical differences between the ages, body weights, or duration of surgery between groups.

five patients. Intubating scores in the succinylcholine group were zero in 16 patients, one in one patient and two in three patients (Table III). Tracheal intubation was easily performed in all patients and there was no significant difference in intubating scores for the two groups.

The initial dose of atracurium produced adequate neuromuscular block for the duration of surgery in Group A. In Group B, the duration of action of the initial dose of succinylcholine was $6.3 \pm 3.2$ minutes. All patients in this group required supplemental doses of succinylcholine. The number of doses required was $2.2 \pm 1.0$. The total dose of succinylcholine given was $103.3 \pm 27.1 \mathrm{mg}$ (Table II).

There was no response to TOF stimulation at the end of surgery in the succinylcholine group. In the atracurium group $(n=20), 17$ patients showed no response to TOF stimulation prior to injection of neostigmine and in the other three patients, only the first response to TOF stimulation was present.

The time from injection of neostigmine to recovery of responses of TOF stimulation with no

TABLE III Time to maximum neuromuscular block (onset) and intubating scores

\begin{tabular}{|c|c|c|c|c|}
\hline & \multirow{2}{*}{$\begin{array}{l}\text { Onset (sec) } \\
\text { Mean } \pm S . D .\end{array}$} & \multicolumn{3}{|c|}{$\begin{array}{l}\text { Intubating } \\
\text { Scores }\end{array}$} \\
\hline & & 0 & $I$ & 2 \\
\hline \multicolumn{5}{|l|}{ Group A. (n $=20)$} \\
\hline Atracurium $400 \mu \mathrm{g} \cdot \mathrm{kg}^{-1} \mathrm{~B} . \mathrm{W}$. & $198.3 \pm 84.1$ & 10 & 5 & 5 \\
\hline \multicolumn{5}{|l|}{ Group B. $(n=20)$} \\
\hline Succinylcholine $1 \mathrm{mg} \cdot \mathrm{kg}^{-1} \mathrm{~B} . \mathrm{W}$. & $76.7 \pm 39.3$ & 16 & 1 & 3 \\
\hline
\end{tabular}

Complete neuromuscular block was produced faster with succinylcholine $(\mathrm{p}<0.01)$.

There was no significant difference in intubating scores. fade was $5.05 \pm 4.6$ minutes (range $1-20$ minutes, median 3.5 minutes) in the study group. In the same group, head lift to command, sustained for five seconds or more, was achieved within five minutes after extubation in 14 patients, and ten minutes in three patients. Three patients required repeat doses of neostigmine and atropine and in these patients, sustained head lift to command was achieved in 15 minutes after extubation in two patients, and 20 minutes in one patient.

In the succinylcholine group, recovery of all responses to TOF stimulation occurred in a mean time of $3.9 \pm 1.4$ minutes following the last supplemental dose. Sustained head lift for five seconds to command was achieved within five minutes after extubation in 12 patients, ten minutes in four patients, 15 minutes in two patients and 20 minutes in two patients. There was no significant difference between the two groups in the time to sustained head lift (for five seconds or more) on command after extubation.

\section{Discussion}

The suggested criteria for an ideal muscle relaxant for short procedures are: rapid onset of complete paralysis, early recovery and minimal side effects. ${ }^{5}$ None of the muscle relaxants in clinical use meet all these criteria.

Succinylcholine has a rapid onset of action but has too many side effects. ${ }^{6}$ The older nondepolarising muscle relaxants, d-tubocurarine, gallamine, alcuronium, and fazadinium all have a slow onset, long duration and many side effects. ${ }^{7}$

In a previous study, it was shown that vecuronium $100 \mu \mathrm{g} \cdot \mathrm{kg}^{-1}$ produced adequate muscle relaxation and was easily reversed following procedures lasting less than 30 minutes. ${ }^{5}$ However, the mean time taken to produce complete neuromuscular 
block by vecuronium in that study, 230 seconds, was significantly longer than with succinylcholine. The mean time taken to produce complete paralysis by atracurium in this study was 198 seconds, which is also significantly slower than the onset time of succinylcholine. The onset time for atracurium has been found to be shorter than pancuronium. ${ }^{9,10}$ Therefore, in a situation where rapid intubation is required, succinylcholine remains the drug of choice.

The degree of residual neuromuscular block with atracurium at the end of surgery in this study, as shown by the absence of response to TOF stimulation or the presence of only the first response to TOF stimulation, corresponds to more than 90 per cent depression of first twitch height ${ }^{11}$ and would provide adequate surgical relaxation. ${ }^{12}$ From this state of intense neuromuscular block with atracurium, recovery of all responses to TOF stimulation was achieved in a mean time of $5 \pm 4.6$ minutes following administration of neostigmine. Thus the neuromuscular effect of atracurium $400 \mu \mathrm{g} \cdot \mathrm{kg}^{-1}$ can be reversed with standard doses of neostigmine, less than 20 minutes after injection of relaxant. In contrast, with pancuronium and d-tubocurarine, such profound neuromuscular block may be difficult to reverse, even with larger doses $(5 \mathrm{mg})$ of neostigmine. ${ }^{13}$

Atracurium may be easy to reverse because of its unique mode of elimination from the body. It is metabolised by Hofmann elimination, a nonenzymatic process which is $\mathrm{pH}$ and temperature dependent ${ }^{1,3,14}$ but is independent of renal or hepatic factors. ${ }^{15.16}$ Spontaneous recovery from neuromuscular block with atracurium occurs more rapidly than following pancuronium, d-tubocurarine and gallamine. ${ }^{17}$ Since the antagonism of neuromuscular blocking drugs may be considered as an acceleration of spontaneous recovery, ${ }^{18}$ anticholinesterase-induced recovery can be expected to occur more rapidly after atracurium.

Successful reversal of neuromuscular block following atracurium in this study occurred despite the presence of 90-100 per cent residual block at the time of reversal with neostigmine. Similarly in a previous study, neuromuscular block from vecuronium was successfully reversed when residual block was assessed to be more than 90 per cent in 19 out of 20 patients. ${ }^{5}$ Therefore, it would seem that reversal of the new non-depolarising muscle relax- ants vecuronium and atracurium with neostigmine, from more than 90 per cent twitch depression, is possible, unlike the older non-depolarising relaxants, d-tubocurarine and pancuronium. ${ }^{17}$ However, close monitoring of neuromuscular function is required in order to ensure complete reversal of neuromuscular block following short procedures.

We conclude that atracurium in a dose of 400 $\mu \mathrm{g} \cdot \mathrm{kg}^{-1}$ is suitable for short surgical procedures lasting for less than 30 minutes. Good intubating conditions are achieved in about three minutes. Full neuromuscular block is produced and this can be reversed with standard doses of anticholinesterase drugs less than 20 minutes after the initial dose of muscle relaxant. Monitoring of neuromuscular function is recommended. When succinylcholine is regarded as unsuitable or contraindicated, atracurium may be the drug of choice for short surgical procedures.

\section{Acknowledgements}

The authors thank Professor Richard I. Bodman, Department of Anesthesiology and Dr. Sundar Rao, Department of Biostatistics for their advice and Mr. Emmanuel I. Lapak for typing this manuscript.

\section{References}

1 Stenlake JB, Waigh J, Unwin J, Dewar GH, Coker $G G$. Atracurium: conception and inception. $\mathrm{Br} \mathrm{J}$ Anaesth 1983; 55: (Suppl. 1) 3S-10S.

2 Hughes R, Payne JP. Clinical assessment of atracurium using the single twitch and tetanic responses of the adductor pollicis muscles. Br J Anaesth 1983; 55: (Suppl. 1) 47S-57S.

3 Hughes R, Chapple DJ. The pharmacology of atracurium: a new competetive neuromuscular agent. Br J Anaesth 1983; 53; 31-44.

4 Basta SJ. Ali HH, Savarese JJ et al. Clinical pharmacology of atracurium besylate (BW 33A). A new non-depolarising muscle relaxant. Anaesth Analg 1982; 61, 723-9.

5 Gyasi H, Williams A, Melloni C, Bevan DR. ORG NC $\mathbf{4 5}$ for short intra-abdominal operations: a comparison with succinylcholine. Can Anaesth Soc J, 1983; 30: 132-5.

6 Durant NN, Katz RL. Suxamethonium. Br J Anaesth 1982; 54: 195-208.

7 Feldman SA. Muscle relaxants. 2nd Ed. W.B. Saunders Co. 1979; pp 190-205.

8 Fahey MR, Morris RB, Miller RD, John YJ, 
Cronelly $R$, Gencarelli $P$. Clinical pharmacology of ORG NC45 (Norcuron): a new non-depolarising muscule relaxant. Anesthesiology, 1981; 55: 6-11.

9 Gramstad L, Lilleaasen P, Minsas B. Onset time and duration of action for atracurium, ORG NC45 and pancuronium. Br J Anaesth 1982; 54: 827-30

10 Schiller DJ, Feldman SA. Comparison of intubating conditions with atracurium, vecuronium and pancuronium. Anaesthesia 1984; 39: 1188-91.

11 Lee, C. Train-of-4 quantitation of competetive neuromuscular block. Anesth Analg 1975; 54 : 639-53.

12 Viby-Mogensen J. Clinical assessment of neuromuscular transmission. Br J Anaesth 1982; 54: 209-23.

13 Lee C, Katz RL. Neuromuscular pharmacology: A clinical update and commentary. Br J Anaesth 1980; 52: 173-88.

14 Neill EAM, Chapple DJ, Thompson CW. Metabolism and kinetics of atracurium: an overview. $\mathrm{Br}$ J Anaesth 1983; 55: (Suppl. 1) 23S-25S.

15 Ward S, Neil EAM. Phamacokinetics of atracurium in acute hepatic failure (with acute renal failure). Br J Anaesth; 55: 1169-72.

16 Gyasi $H K$, Naguib $M$. Atracurium and severe hepatic disease: a case report. Can Anaesth Soc J 1985, 32: 161-4

17 Donati F, Bevan JC, Bevan DR. Neuromuscular blocking drugs in anaesthesia. Can Anaesth Soc J 1984; 31: 324-35.

18 Bevan DR. Neuromuscular blocking drugs. Can Anaesth Soc J 1983; 30: 556-61.
Résumé

Lors des procédures gynécologiques de courte durée ( 30 minutes ou moins), l'atracurium a été comparé à la succinylcholine chez 40 patientes. La fonction neuromusculaire a été évaluée par observation de la réponse de l'adducteur du pouce après stimulation avec une ondée de quatre (T.O.F.).

Des bonnes conditions d'intubation ont été produites après $76.7 \pm 39.3$ secondes avec la succinycholine $1 \mathrm{mg} \cdot \mathrm{kg}^{-1}$ et $198 \pm 84$ secondes avec l'atracurium $400 \mu \mathrm{g} \cdot \mathrm{kg}^{-1}$. Le relachement musculaire a êté maintenu avec la dose initiale d' atracurium ou des doses répétées de succinylcholine. Le temps chirurgical moyen était de $17.65 \pm 5.3$ minutes pour le groupe atracurium et $15.2 \pm$ 4.6 minutes pour le groupe succinycholine.

Le bloc neuromusculaire résiduel avec l'atracurium a été antagonisé avec de la néostigmine $0.036 \mathrm{mg} \cdot \mathrm{kg}^{-1}$ et de l'atropine $0.018 \mathrm{mg} \cdot \mathrm{kg}^{-1}$. La reprise de la fonction neuromusculaire après antagonisme, évaluée par le retour des réponses à la stimulation du T.O.F. et survenue après $5.05 \pm 4.6$ minutes pour le groupe atracurium. Il faut cependant noter que la moitié des doses d'antagoniste sus-mentionnées a été répétée pour trois patientes. Dans la periode post opératoire aucune complication ne fut notée dans les deux groupes.

On conclut qu'une dose unique d'atracurium de $400 \mu \mathrm{g} \cdot \mathrm{kg}^{-1}$ est convenable pour l'intubation et le maintien $d u$ relachement musculaire lors des procédures chirurgicales de courte durée. Cependant le début d'action est lent comparativement à la succinylcholine. Un bloc neuromusculaire résiduel peut être antagonisé avec des doses standard de neostigmine moins que 20 minutes après la dose initiale de relarant. L'atracurium apparaît comme étant une alternative convenable pour des procédures de courte durée lorsque que la succinylcholine est contraindiquée ou déconseillée. 